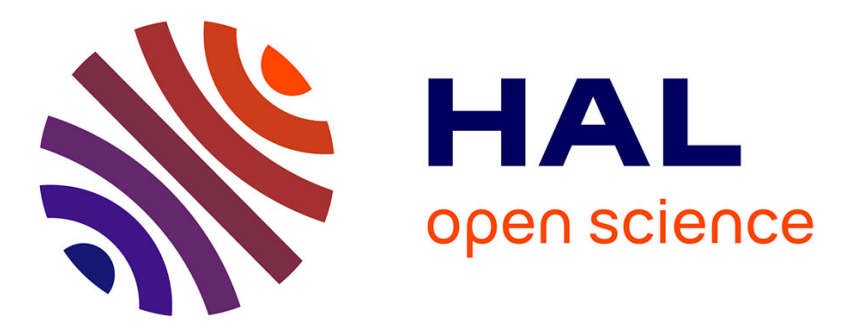

\title{
Physicochemical characterization of inorganic deposits associated with granulomas in cutaneous sarcoidosis
}

\author{
H. Colboc, P. Moguelet, D. Bazin, C. Bachmeyer, V. Frochot, R. Weil, E.
} Letavernier, C. Jouanneau, M. Daudon, J.F. F Bernaudin

\section{- To cite this version:}

H. Colboc, P. Moguelet, D. Bazin, C. Bachmeyer, V. Frochot, et al.. Physicochemical characterization of inorganic deposits associated with granulomas in cutaneous sarcoidosis. Journal of the European Academy of Dermatology and Venereology, 2019, 33 (1), pp.198-203. 10.1111/jdv.15167 . hal-01962071

\section{HAL Id: hal-01962071 \\ https://hal.sorbonne-universite.fr/hal-01962071}

Submitted on 20 Dec 2018

HAL is a multi-disciplinary open access archive for the deposit and dissemination of scientific research documents, whether they are published or not. The documents may come from teaching and research institutions in France or abroad, or from public or private research centers.
L'archive ouverte pluridisciplinaire HAL, est destinée au dépôt et à la diffusion de documents scientifiques de niveau recherche, publiés ou non, émanant des établissements d'enseignement et de recherche français ou étrangers, des laboratoires publics ou privés. 
MRS. HESTER COLBOC (Orcid ID : 0000-0001-8756-9862)

Article type : Short Report

Physicochemical characterization of inorganic deposits associated with granulomas in cutaneous sarcoidosis.

Running head: Inorganic deposits in skin sarcoidosis
H. Colboc ${ }^{1,8,10}$, P. Moguelet ${ }^{2,10}$,
D. $\operatorname{Bazin}^{3,4,10}$,
C. Bachmeyer ${ }^{5}$, V. Frochot ${ }^{6,7}$, R. Weil ${ }^{4}$, E.
Letavernier $^{6,7}$, C. Jouanneau ${ }^{7}$, M. Daudon ${ }^{6,7,11}$, J.F. Bernaudin ${ }^{8,9,11}$

1. AP-HP, Hôpital Rothschild, Dermatologie, Paris, France,

2. AP-HP, Hôpital Tenon, Anatomie et Cytologie Pathologiques, Paris, France,

3. Sorbonne Université, UPMC Université Paris 06, CNRS, Collège de France, Laboratoire de Chimie de la Matière Condensée de Paris, 11 place Marcelin Berthelot, 75005, Paris, France,

4. CNRS, LPS, Ba510, Université Paris XI, 91405 Orsay, France,

5. AP-HP, Hôpital Tenon, Médecine interne, Paris, France,

6. Sorbonne Université, UPMC Université Paris 06, UMR S 1155, Paris, France, 
7. AP-HP, Hôpital Tenon, Explorations Fonctionnelles Multidisciplinaires, Paris, France,

8. Sorbonne Université, UPMC Université Paris 06, Paris, France,

9. AP-HP Service de pneumologie, Hôpital Avicenne 93000 Bobigny France

10. These authors contributed equally to this work.

11. These authors should be considered joint last authors

Corresponding author:

Hester Colboc, MD

Hôpital Rothschild

5 , rue Santerre

75012 Paris, France

Tel : 0140193349

Fax : 0140193397

hester.colboc@aphp.fr

Conflicts of interest: none declared

Funding sources: none declared 


\begin{abstract}
Background. Sarcoidosis, characterized by epithelioid granulomas, is considered to be caused by a complex interplay between genetics and environmental agents. It has been hypothesized that exogenous inorganic particles as crystalline silica could be a causal or adjuvant agent in sarcoidosis onset.
\end{abstract}

Objectives. To investigate the location, frequency and physicochemical characteristics of foreign materials and mineral tissue deposits in the granulomatous area of cutaneous sarcoidosis.

Methods. Skin biopsies $(n=14)$ from patients diagnosed with cutaneous sarcoidosis (mean age 43 years; 11 patients with extra-cutaneous involvement) were investigated using polarized light examination (PLE), $\mu$ Fourier Transform Infra-Red ( $\mu$ FT-IR) spectroscopy and Field Emission Scanning Electron Microscopy coupled with Energy Dispersive X-ray Spectroscopy (FE-SEM/EDX)

Results. Combined PLE, $\mu$ FT-IR, FE-SEM/EDX analysis allowed to characterize mineral deposits in 7/14 biopsies (50\%). It identified crystalline silica $\left(\mathrm{SiO}_{2}\right)$ inside granulomas in 3 biopsies and calcite $\left(\mathrm{CaCO}_{3}\right)$ at their periphery in 4 .

Conclusion. This study emphasizes the need of using combined methods for assessment of mineral deposits in granulomatous diseases. According to the location and characteristics of deposits we can hypothesize that $\mathrm{SiO}_{2}$ particles contribute to the granuloma formation, whereas $\mathrm{CaCO}_{3}$ deposits are related to the granuloma biology. However, the significance of the association between $\mathrm{SiO}_{2}$ deposits and sarcoidosis is still disputed. 


\section{Introduction}

Sarcoidosis is characterized by an exaggerated granulomatous response mostly affecting the lung, skin and eye, locations particularly exposed to exogenous particulates. ${ }^{1-2}$ Granuloma mostly constituted of macrophage lineage cells is thought to be controlled by innate as well as adaptive immune mechanisms in a complex combination of genetic susceptibility, immune networks and infectious and/or environmental agents. ${ }^{3}$

Sarcoidosis affects the skin in $25-30 \%$ of patients and manifests by a wide range of clinical cutaneous lesions. ${ }^{4-5}$ It is well known that sarcoidosis preferentially affects sites with a prior injury as tattoos or scars. Polarizable material has been reported up to $22 \%$ of the cases suggesting that foreign material could be a nidus for granuloma formation and a potential trigger for the disease. ${ }^{6-8}$

This study, based on a series of cutaneous biopsies of sarcoidosis, was designed to investigate the frequency and physicochemical characterization of mineral deposits in the granulomatous areas. To describe their characteristics at the subcellular scale as well as their chemical nature, in addition to polarized light examination (PLE), two different techniques of physicochemical analysis were used: $\mu$ Fourier Transform Infra-Red ( $\mu$ FT-IR) spectroscopy and Field Emission Scanning Electron Microscopy coupled with Energy Dispersive X-ray Spectroscopy (FE-SEM/EDX). ${ }^{9}$ Such a combination of methods has been amply demonstrated to be particularly effective for detection and physicochemical identification of inorganic/ mineral deposits in various tissue samples. ${ }^{10}$ 


\section{Material and methods}

\section{Skin biopsies, histopathology and polarized light examination}

The study was conducted in compliance with Good Clinical Practices and the Declaration of Helsinki, according to French law.

A retrospective monocentric study was conducted, from January 2012 to December 2015. Consecutive patients diagnosed with skin sarcoidosis during this period, based on clinical data and histopathology results, were included. Clinical and biological data, including demographic, occupation, past medical history, extra-cutaneous involvement of the disease, clinical description and location of the skin lesions, calcium and angiotensin converting enzyme serum levels were collected.

Five samples from negative margins of skin carcinoma resections were included and further described as controls.

Multiples sections of $1.5 \mu \mathrm{m}$ from paraffin embedded skin biopsies were obtained and deposited on two types of slides: glass slides, for hematoxylin-eosin-saffron (HES), and lowe microscope slides (MirrIR, Kevley Technologies, Tienta Sciences, Indianapolis) for FESEM/EDX and $\mu$ FT-IR. The location (superficial and deep dermis, sub-cutis) and number of granulomas observed per biopsy were evaluated. A screening by PLE was done by two different pathologists.

Skin sections were analysed and compared between cases and controls, for the presence of abnormal deposits. 


\section{Physicochemical analysis of mineral deposits}

The tools and methods have been extensively described in a thematic issue of the Comptes Rendus Chimie de l'Académie des Sciences Paris France. ${ }^{11}$

Briefly, for $\mu \mathrm{FT}$-IR, tissue sections deposited on low-e microscope slides were analyzed with the Spotlight 400 FTIR imaging System (Perkin Elmer Life Sciences - Courtaboeuf, France), in the mid infrared (4000-700 cm-1) spectral range to obtain infrared maps of tissue slides at high spatial resolution, down to $10 \mu \mathrm{m} .^{9}$

For FE-SEM/EDX the sections previously used for $\mu$ FT-IR were observed on a Zeiss SUPRA55-VP SEM (Zeiss SUPRA55-VP - Oberkochen, Germany) equipped with in-lens SE and Everharte Thornley SE secondary electron detectors. ${ }^{12}$ Energy Dispersive X-ray spectroscopy (EDX) coupled to FE-SEM observation was used to confirm the nature of the deposits.

\section{Results}

\section{Skin biopsies, histopathology and polarized light examination (PLE)}

Sixteen patients were diagnosed with skin sarcoidosis at Tenon Hospital from January 2012 to December 2015. Two patients were excluded because the tissue sample available for analysis was too small. Finally, cutaneous biopsies from 14 patients ( 9 men; 5 women) were selected for further analysis. Demographic, clinical and histopathological characteristics of all patients are summarized in Table 1 and for each patient in table 2 (supplementary material). Eleven patients had associated extracutaneous localizations of sarcoidosis mostly pulmonary 
$(n=10)$. One of the three patients without extracutaneous localization, (patient 8 in table 2 supplementary material) had a single granulomatous lesion of the forehead and the diagnosis of "localized sarcoidosis-like granulomatous reaction" could not be excluded. For PLE from 4 to 33 (mean=16) sections per biopsy were analyzed. Refractive material was detected in 5 biopsies, restricted to one or two granulomas per section (Fig. 1). Interstitial peri granulomatous fibrosis was observed in 13 cases without any polarized signal observed in this area.

\section{Physicochemical analysis of mineral deposits}

\section{Intra granuloma mineral silica $\left(\mathrm{SiO}_{2}\right)$ deposits}

In 3 biopsies with PLE refractive material, $\mu$ FT-IR characterized mineral silica deposits (Fig. 2).

FE-SEM observation showed that silica particles were inside the granulomas. In two samples, the deposits were sharp, unique, irregular objects more than $10 \mu \mathrm{m}$ long. In the third, the deposit was an aggregate of very small objects some of them at the nanoparticle scale. No other nanoparticles of $\mathrm{SiO}_{2}$ were observed within the granuloma or in its vicinity. EDX analysis confirmed the presence of silica in these 3 samples (Fig. 2).

\section{Peripheral calcium carbonate $\left(\mathrm{CaCO}_{3}\right)$ deposits}

$\mu$ FT-IR analysis of 4 biopsies detected calcite $\left(\mathrm{CaCO}_{3}\right)$ deposits in the form of calcite at the periphery of the granulomas. FE-SEM/EDX showed aggregates of submicrometer spherical 
deposits of calcite located between the collagen fibers (Fig. 3). Two of these 4 patients had hypercalcemia.

\section{Controls}

Similar analyses were performed on the 5 samples from the control group, no deposits were found either in dermis or subcutis.

\section{Discussion}

Using combined methods, we yield comprehensive information on the location and physicochemical nature of inorganic deposits in granulomas (crystalline silica $\mathrm{SiO}_{2}$ ) and perigranuloma tissues (calcite $\mathrm{CaCO}_{3}$ ) in patients with cutaneous sarcoidosis. We identified crystalline silica $\left(\mathrm{SiO}_{2}\right)$ inside granulomas in 3 biopsies and calcium carbonate $\left(\mathrm{CaCO}_{3}\right)$ at their periphery in 4 .

Refractive material was observed by PLE in 5 biopsies (35\%) which is in accordance with the $20 \%-78 \%$ reported range. ${ }^{7}$ In our series, $\mu$ FT-IR showed silica deposits in 3 biopsies $(21 \%)$ which has been confirmed to be crystalline silica by FE-SEM/EDX. For one of these biopsies the PLE examination was negative, while for 3 PLE positive samples infrared spectroscopy identified calcium carbonate deposits.

Crystalline silica was identified in granulomas in 3 biopsies from environment exposed skin areas (elbow, arm and forehead). This finding is in keeping with the origin of $\mathrm{SiO}_{2}$ deposits in relation to environmental or occupational exposure. For one patient the area has previously been affected by a trauma which could have been responsible for deposition of foreign 
bodies. Accordingly to epidemiological studies, crystalline silica has been suggested to play a role in sarcoidosis occurrence particularly after environmental or occupational exposure. ${ }^{13}$ However, in the present study identification of $\mathrm{SiO}_{2}$ particles has been a particularly rare event affecting at least 1 granuloma section among a mean of 75 analyzed per biopsy. But it cannot be excluded that the frequency of deposits was largely underestimated. As each granuloma has a mean diameter of at least $150-200 \mu \mathrm{m},{ }^{14} 5 \mu \mathrm{m}$ sections correspond to a very limited fraction of the lesion. In addition, loss of these hard particles deposits may occur during the processing of tissue sample particularly at the sectioning step. SEM examination showed that $\mathrm{SiO}_{2}$ particles were observed as unique intracellular deposits. It has been hypothesized that nanoparticles of silica undetected by PLE could be a causative agent in sarcoidosis. ${ }^{15}$ The significance of the frequent association between foreign material and sarcoidosis is still controversial. ${ }^{8}$ Foreign bodies may be initial triggers for sarcoidosis constituting the nidus for granulomas in patients with a particular genetic background having an impaired capacity to handle particulate foreign material. ${ }^{16-17}$ Conversely another hypothesis is to consider granuloma in sarcoidosis as a host related inflammatory/ immune reaction non-specific of a special antigen or particulate occurring at sites where potential incidental triggering agents (scars, foreign material, antigens...) are already located. In line with this hypothesis is the observation of granuloma recurrence on tattoos or scars in parallel with exacerbation or relapse of systemic sarcoidosis. ${ }^{18}$

Calcite deposits were observed at distance from granulomas, within the connective tissue of dermis in 4 patients, two with hypercalcemia. Calcium oxalate and phosphate deposits have been reported in sarcoidosis, however, to the best of our knowledge, we report the first cases of calcite deposits. ${ }^{19}$ Presence at the nanometer scale of these deposits, including in patients with normal serum calcium level, raises the question that calcium carbonate deposits in 
tissues around granulomas could be a common not yet highlighted finding in conjunction with the role of the granuloma in vitamin $\mathrm{D}$ and calcium metabolism. ${ }^{20}$

In conclusion such a study needs to be extended to samples from other organs affected by sarcoidosis, mostly lung and mediastinal lymph nodes exposed to environmental and occupational pollutants. Moreover the consequence of calcite deposits in organs where granulomas develop should be investigated.

\section{Acknowledgments}

We thank Pr Camille Frances, from the department of Dermatology Tenon Hospital Paris, Prs Dominique Valeyre and Jean-Paul Battesti, from Avicenne Hospital Bobigny France, and PA Rosental from Sciences Po Paris for their constant support and fruitful discussions.

\section{References}

1 Valeyre D, Prasse A, Nunes H, Uzunhan Y, Brillet P-Y, Müller-Quernheim J. Sarcoidosis. Lancet 2014; 383:1155-1167.

2 Baughman RP, Teirstein AS, Judson MA, et al. Clinical characteristics of patients in a case control study of sarcoidosis. Am J Respir Crit Care Med 2001; 164:1885-1889.

3 Müller-Quernheim J, Schürmann M, Hofmann S, et al. Genetics of sarcoidosis. Clin Chest Med 2008; 29: 391-414.

4 Wanat KA, Rosenbach M. Cutaneous Sarcoidosis. Clin Chest Med 2015; 36: 685-702. 
5 Haimovic A, Sanchez M, Judson MA, Prystowsky S. Sarcoidosis: a comprehensive review and update for the dermatologist: part II. Extracutaneous disease. J Am Acad Dermatol 2012; 66: 719-730.

6 Callen JP. The presence of foreign bodies does not exclude the diagnosis of sarcoidosis. Arch Dermatol 2001; 137: 485-486.

7 Marcoval J, Moreno A, Maña J. Foreign bodies in cutaneous sarcoidosis. J Cutan Pathol 2004; 31: 516.

8 Sepehri M, Hutton Carlsen K, Serup J. Papulo-Nodular Reactions in Black Tattoos as Markers of Sarcoidosis: Study of 92 Tattoo Reactions from a Hospital Material. Dermatol Basel Switz 2016; 232: 679-686.

9 Bazin D, Daudon M. Some advances in the field of physico-chemical characterization of pathological microcrystals. Ann Biol Clin 2015; 73: 517-534.

10 Dessombz A, Bazin D, Dumas P, Sandt C, Sule-Suso J, Daudon M. Shedding light on the chemical diversity of ectopic calcifications in kidney tissues: diagnostic and research aspects. PloS One 2011; 6: e28007.

11 Colboc H, Bazin D, Moguelet P, et al. Detection of silica and calcium carbonate deposits in granulomatous areas of skin sarcoidosis by $\mu$ Fourier transform infrared spectroscopy and Field Emission Scanning Electron Microscopy coupled with Energy Dispersive Xray Spectroscopy analysis. Comptes Rendus Chim 2016; 19: 1631-1641.

12 Brisset F. Microscopie électronique à balayage et microanalyses. EDP sciences 2012. 
13 Rafnsson V, Ingimarsson $\mathrm{O}$, Hjalmarsson I, Gunnarsdottir H. Association between exposure to crystalline silica and risk of sarcoidosis. Occup Environ Med 1998; 55: 657-660.

14 Kambouchner M, Pirici D, Uhl J-F, Mogoanta L, Valeyre D, Bernaudin J-F. Lymphatic and blood microvasculature organisation in pulmonary sarcoid granulomas. Eur Respir J 2011; 37: 835-840.

15 Heffner DK. The cause of sarcoidosis: the Centurial enigma solved. Ann Diagn Pathol 2007; 11: 142-152.

16 Walsh NM, Hanly JG, Tremaine R, Murray S. Cutaneous sarcoidosis and foreign bodies. Am J Dermatopathol 1993; 15: 203-207.

17 Fingerlin TE, Hamzeh N, Maier LA. Genetics of Sarcoidosis. Clin Chest Med 2015; 36: $569-584$.

18 Schiavo AL, Ruocco E, Gambardella A, O’Leary RE, Gee S. Granulomatous dysimmune reactions (sarcoidosis, granuloma annulare, and others) on differently injured skin areas. Clin Dermatol 2014; 32: 646-653.

19 Reid JD, Andersen ME. Calcium Oxalate in Sarcoid Granulomas: With Particular Reference to the Small Ovoid Body and a Note on the Finding of Dolomite. Am J Clin Pathol 1988; 90: 545-558.

20 Berlin JL, Shantha GP, Yeager H, Thomas-Hemak L. Serum vitamin D levels may not reflect tissue-level vitamin D in sarcoidosis. BMJ Case Rep 2014; 2014: 1-4. 
Table 1 Demographic, clinical and histopathological data of cases

\begin{tabular}{|c|c|}
\hline & $\mathbf{N}(\%)$ \\
\hline Patient's characteristics & 14 \\
\hline Men / Female & $9 / 5$ \\
\hline Age at inclusion (years) & $43(23-68)$ \\
\hline \multicolumn{2}{|l|}{ Type of lesions } \\
\hline Nodules & $7(50)$ \\
\hline Papules & $6(43)$ \\
\hline Plaques & $1(7)$ \\
\hline \multicolumn{2}{|l|}{ Localisation } \\
\hline Lower limbs & $5(36)$ \\
\hline Face & $5(36)$ \\
\hline Upper Limbs & $4(29)$ \\
\hline Trunk & $2(14)$ \\
\hline \multicolumn{2}{|l|}{ Treatment } \\
\hline Hydroxychloroquine & $7(50)$ \\
\hline Systemic corticosteroids & $5(36)$ \\
\hline Immunosuppressive therapy & $4(29)$ \\
\hline Local corticosteroids & $2(14)$ \\
\hline No treatment & $1(7)$ \\
\hline Extra cutaneous localisations & $11(79)$ \\
\hline Pulmonary & $10(71)$ \\
\hline Renal & $2(14)$ \\
\hline Osteo-articular & $2(14)$ \\
\hline Neurological & $1(7)$ \\
\hline Ophthalmological & $1(7)$ \\
\hline Occupational exposure to mineral dusts & $4(29)$ \\
\hline
\end{tabular}




\begin{tabular}{|l|l|}
\hline $\begin{array}{l}\text { Biology } \\
\text { Hypercalcemia * }\end{array}$ & $2(14)$ \\
Elevated angiotensin converting enzyme level & $4(29)$ \\
\hline $\begin{array}{l}\text { Number of granulomas per section } \\
\leq 10\end{array}$ & $5(33)$ \\
10 to 50 & $6(40)$ \\
$>50$ & $4(26)$ \\
\hline Localisation of the granulomas & $11(73)$ \\
Duperficial dermis & $10(67)$ \\
Hypodermis & $5(33)$ \\
& \\
\hline Presence of refractive material & $5(33)$ \\
\hline
\end{tabular}

* Defined as serum calcium level $>2.6 \mathrm{mmol} / \mathrm{l}$ 


\section{Figure legends}

Figure 1 Optic microscopy, PLE and SEM of granulomas in cutaneous sarcoidosis. (a) Optic microscopy of a characteristic cutaneous granuloma (HES x 200). (b) PLE of the same granuloma, showing birefringent particles. (c) Optical microscopy of another granuloma (HES x 400); (d) PLE, showing birefringent particles. (e-f) SEM photographs showing an intragranuloma inorganic deposit at two magnifications.

Figure 2 Examples of physicochemical analysis of the mineral silica $\left(\mathrm{SiO}_{2}\right)$ deposits observed within a granuloma. (a) $\mu \mathrm{FT}-\mathrm{IR}$ microspectroscopy: IR spectrum showing the characteristic signals of silica in the protein matrix of a granuloma. (b) FE-SEM/EDX the EDAX spectrum identifies the presence of a significant signal related to silicon ( $\mathrm{Si})$ in the deposit $(1.740 \mathrm{keV}$ $\left.\mathrm{cm}^{-1}\right)$

Figure 3 Detection and physicochemical analysis of calcite $\left(\mathrm{CaCO}_{3}\right)$ deposits at the periphery of granulomas. (a) SEM photograph showing aggregates of submicrometer spherical deposits localized between the collagen fibers (arrow). (b) $\mu \mathrm{FT}-\mathrm{IR}$ microspectroscopy: IR spectrum showing the characteristic peaks of calcite $\left(\mathrm{CaCO}^{3}\right)$. (c) FE-SEM/EDX: the EDAX spectrum identifies the presence of a significant signal related to calcium $(\mathrm{Ca} ; 3.7 \mathrm{keV})$ and the absence of a signal from phosphore $(\mathrm{P} ; 2.01 \mathrm{keV})$ in line with the FTIR spectrum identifying calcite $\left(\mathrm{CaCO}_{3}\right)$. 
Table 1 Demographic, clinical and histopathological data of cases

\begin{tabular}{|l|l|}
\hline & $\mathbf{N}(\%)$ \\
\hline Patient's characteristics & 14 \\
Men / Female & $9 / 5$ \\
Age at inclusion (years) & $43(23-68)$ \\
\hline Type of lesions & \\
Nodules & $7(50)$ \\
Papules & $6(43)$ \\
Plaques & $1(7)$ \\
\hline Localisation & \\
Lower limbs & $5(36)$ \\
Face & $5(36)$ \\
Upper Limbs & $4(29)$ \\
Trunk & $2(14)$ \\
\hline Treatment & \\
Hydroxychloroquine & $7(50)$ \\
Systemic corticosteroids & $5(36)$ \\
Immunosuppressive therapy & $4(29)$ \\
Local corticosteroids & $2(14)$ \\
No treatment & $1(7)$ \\
\hline Extra cutaneous localisations & $11(79)$ \\
Pulmonary & $10(71)$ \\
Renal & $2(14)$ \\
Osteo-articular & $2(14)$ \\
Neurological & $1(7)$ \\
Ophthalmological & $1(7)$ \\
\hline Occupational exposure to mineral dusts & $4(29)$ \\
\hline Biology & \\
Hypercalcemia * & $2(14)$ \\
Elevated angiotensin converting enzyme level & $4(29)$ \\
\hline Number of granulomas per section & $5(33)$ \\
\hline S10 & $6(40)$ \\
10 to 50 & $4(26)$ \\
\hline Localisation of the granulomas & \\
Superficial dermis & $11(73)$ \\
Deep dermis & $10(67)$ \\
Hypodermis & $5(33)$ \\
\hline Presence of refractive material & \\
\hline & $5(33)$ \\
\hline
\end{tabular}

* Defined as serum calcium level $>2.6 \mathrm{mmol} / \mathrm{l}$ 


\begin{tabular}{|c|c|c|c|c|c|c|c|c|c|c|c|}
\hline \multicolumn{3}{|c|}{ Patients } & \multicolumn{3}{|c|}{ Clinical presentation } & \multicolumn{3}{|c|}{ Histopathology } & \multirow{2}{*}{$\begin{array}{l}\text { Calcemia } \\
\text { and } \\
\mathrm{ACE}^{3} \\
\text { level }\end{array}$} & \multirow[t]{2}{*}{ PLE $^{4}$} & \multirow{2}{*}{$\begin{array}{l}\text { Physicochemical } \\
\text { characterization } \\
\text { of the deposits }\end{array}$} \\
\hline & Gender $^{1}$ & age & $\begin{array}{l}\text { Skin } \\
\text { lesions } \\
\text { location }\end{array}$ & $\begin{array}{l}\text { Type of } \\
\text { skin } \\
\text { lesion }\end{array}$ & $\begin{array}{l}\text { Other } \\
\text { organs } \\
\text { involved }\end{array}$ & $\begin{array}{l}\text { Location } \\
\text { of the } \\
\text { biopsy }\end{array}$ & $\begin{array}{l}\text { Number of } \\
\text { granulomas }\end{array}$ & $\begin{array}{l}\text { Granulomas } \\
\text { location }\end{array}$ & & & \\
\hline 1 & $\mathrm{M}$ & 47 & $\begin{array}{l}\text { Upper } \\
\text { and } \\
\text { lower } \\
\text { limbs }\end{array}$ & Nodules & None & $\begin{array}{l}\text { Lower } \\
\text { limb }\end{array}$ & 10 & Subcutis & $\begin{array}{l}\text { Both } \\
\text { normal }\end{array}$ & Positive & Calcium carbonate \\
\hline 2 & $\mathrm{M}$ & 31 & Face & Papules & $\begin{array}{l}\text { Lung, } \\
\text { joint }\end{array}$ & Temple & 21 & $\begin{array}{l}\text { Superficial and } \\
\text { deep dermis }\end{array}$ & $\begin{array}{l}\text { Hypercal- } \\
\text { cemia } \\
\text { Elevated } \\
\text { ACE }\end{array}$ & Negative & Calcium carbonate \\
\hline 3 & $\mathrm{M}$ & 55 & $\begin{array}{l}\text { Lower } \\
\text { limbs }\end{array}$ & Nodules & Lung & $\begin{array}{l}\text { Lower } \\
\text { limb }\end{array}$ & 76 & $\begin{array}{l}\text { Deep dermis and } \\
\text { subcutis }\end{array}$ & $\mathrm{NA}^{5}$ & Positive & Calcium carbonate \\
\hline 4 & $\mathrm{~F}$ & 61 & $\begin{array}{l}\text { Upper } \\
\text { limbs }\end{array}$ & Nodules & Lung & Arm & 33 & $\begin{array}{l}\text { Deep dermis and } \\
\text { subcutis }\end{array}$ & $\begin{array}{l}\text { Both } \\
\text { normal }\end{array}$ & Negative & - \\
\hline 5 & $\mathrm{M}$ & 68 & Toes & Plaques & Lung & Toe & 10 & $\begin{array}{l}\text { Superficial and } \\
\text { deep dermis }\end{array}$ & $\mathrm{NA}^{5}$ & Negative & - \\
\hline 6 & $\mathrm{~F}$ & 43 & $\begin{array}{l}\text { Face, } \\
\text { upper } \\
\text { limbs }\end{array}$ & Nodules & Lung & Elbow & 48 & $\begin{array}{l}\text { Superficial and } \\
\text { deep dermis }\end{array}$ & $\begin{array}{l}\text { Normal } \\
\text { calcemia } \\
\text { Elevated } \\
\text { ACE }\end{array}$ & Negative & Crystalline silica \\
\hline
\end{tabular}




\begin{tabular}{|c|c|c|c|c|c|c|c|c|c|c|c|}
\hline 7 & $\mathrm{M}$ & 42 & $\begin{array}{l}\text { Upper } \\
\text { limbs }\end{array}$ & Nodules & Lung & Arm & 115 & Deep dermis & $\begin{array}{l}\text { Both } \\
\text { normal }\end{array}$ & Positive & Crystalline silica \\
\hline 8 & $\mathrm{~F}$ & 23 & $\begin{array}{l}\text { Fore } \\
\text { Head }\end{array}$ & Nodule & $\mathrm{NA}^{5}$ & $\begin{array}{l}\text { Fore } \\
\text { Head }\end{array}$ & 70 & $\begin{array}{l}\text { Superficial and } \\
\text { deep dermis }\end{array}$ & $\mathrm{NA}^{5}$ & Positive & Crystalline silica \\
\hline 9 & M & 41 & Back & Papules & Kidney & Back & 73 & $\begin{array}{l}\text { Superficial and } \\
\text { deep dermis }\end{array}$ & $\begin{array}{l}\text { Hypercal- } \\
\text { cemia } \\
\text { Normal } \\
\text { ACE }\end{array}$ & Positive & Calcium carbonate \\
\hline 10 & $\mathrm{~F}$ & 51 & Back & Papules & Lung & Back & 7 & $\begin{array}{l}\text { Superficial } \\
\text { dermis }\end{array}$ & $\begin{array}{l}\text { Both } \\
\text { normal }\end{array}$ & Negative & - \\
\hline 11 & M & 38 & $\begin{array}{l}\text { Genitals, } \\
\text { lower } \\
\text { limbs }\end{array}$ & Nodules & $\begin{array}{l}\text { Lung, } \\
\text { Central } \\
\text { nervous } \\
\text { system }\end{array}$ & $\begin{array}{l}\text { Lower } \\
\text { limb }\end{array}$ & 33 & $\begin{array}{l}\text { Deep dermis and } \\
\text { subcutis }\end{array}$ & $\mathrm{NA}^{5}$ & Negative & - \\
\hline 12 & $\mathrm{M}$ & 45 & $\begin{array}{l}\text { Lower } \\
\text { limbs }\end{array}$ & Papules & $\begin{array}{l}\text { Lung, } \\
\text { kidney, } \\
\text { eye }\end{array}$ & $\begin{array}{l}\text { Lower } \\
\text { limb }\end{array}$ & 22 & $\begin{array}{l}\text { Superficial } \\
\text { dermis, deep } \\
\text { dermis and } \\
\text { subcutis }\end{array}$ & $\begin{array}{l}\text { Normal } \\
\text { calcemia } \\
\text { Elevated } \\
\text { ACE }\end{array}$ & Negative & - \\
\hline 13 & $\mathrm{~F}$ & 35 & Scalp & Papules & None & Scalp & 9 & $\begin{array}{l}\text { Superficial } \\
\text { dermis }\end{array}$ & $\begin{array}{l}\text { Both } \\
\text { normal }\end{array}$ & Negative & - \\
\hline 14 & M & 28 & Face & Papules & Lung & Face & 19 & $\begin{array}{l}\text { Superficial and } \\
\text { deep dermis }\end{array}$ & $\begin{array}{l}\text { Normal } \\
\text { calcemia } \\
\text { Elevated } \\
\text { ACE }\end{array}$ & Negative & - \\
\hline
\end{tabular}


Table 2: Patients, histopathology, biology and deposits characterisation in the 14 skin biopsies for cutaneous sarcoidosis.

${ }^{1}$ M: male; F: female

${ }^{2}$ Number of granulomas screened per biopsy

${ }^{3}$ ACE: angiotensin conversing enzyme

${ }^{4}$ PLE: polarized light examination

${ }^{5} \mathrm{NA}$ : not available 

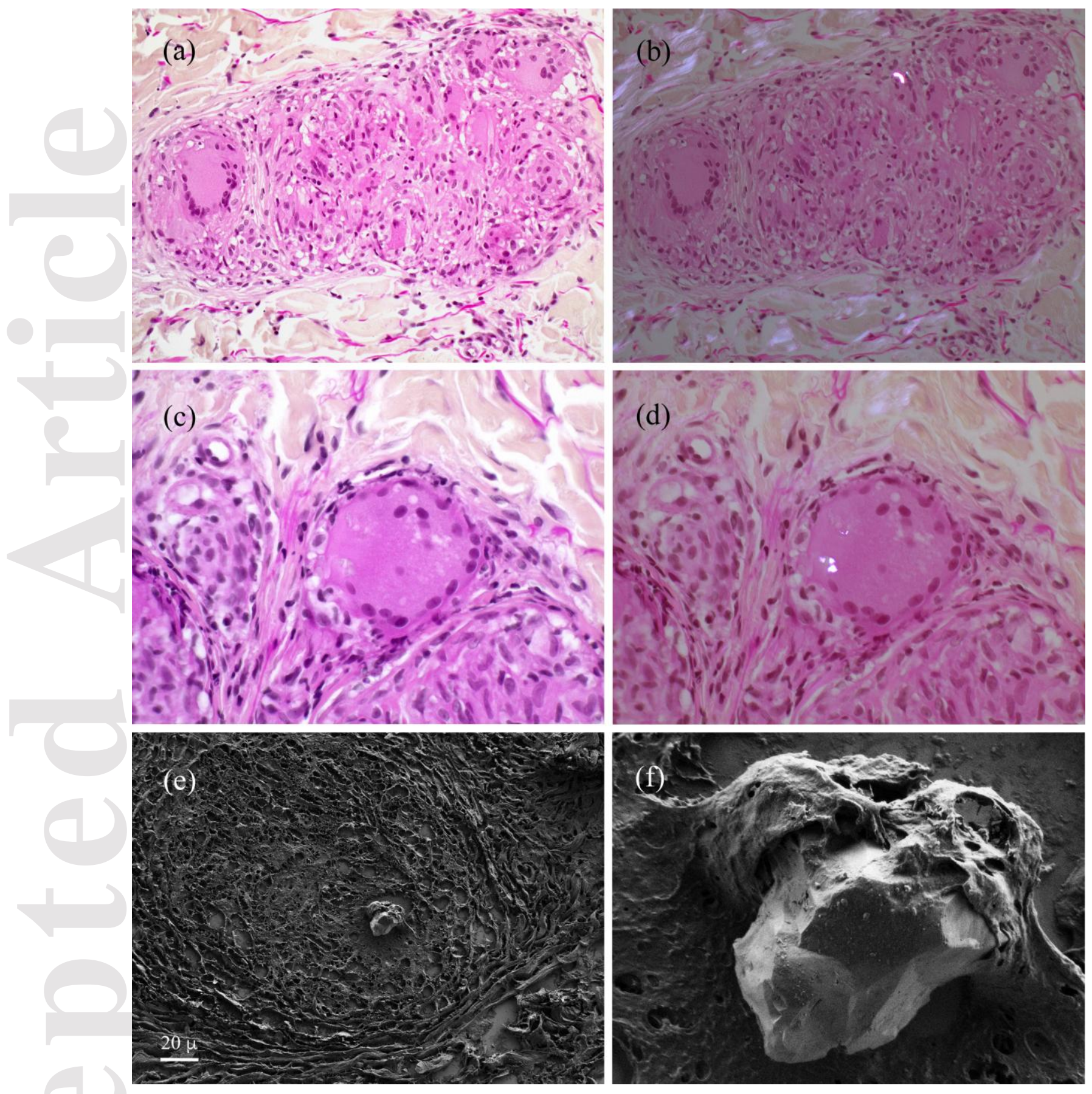

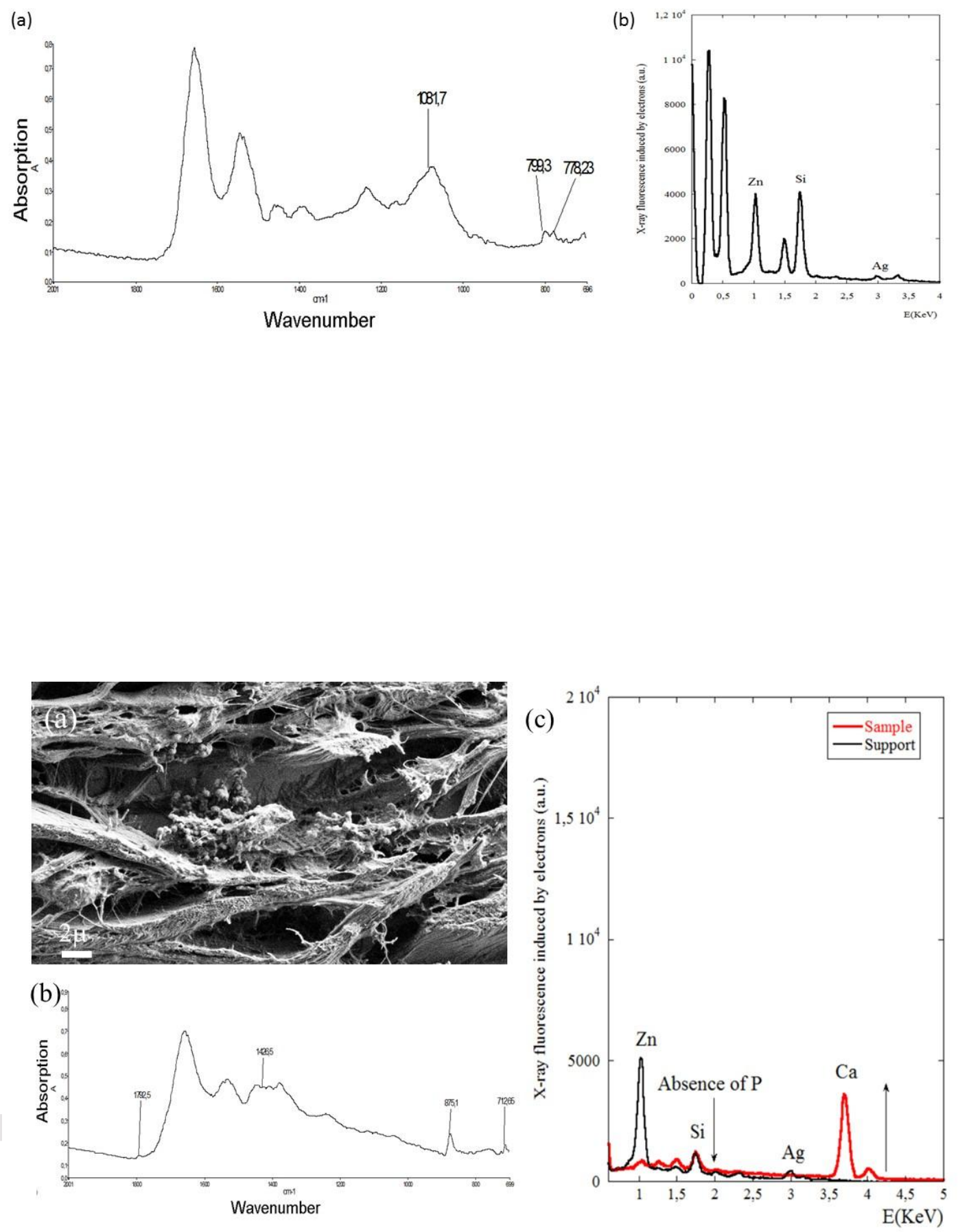